\title{
Pengaruh Electronic Word of Mouth dan Brand Experience terhadap Brand Trust (Studi terhadap pengguna OVO di Jakarta)
}

\author{
Karin Charvia, Rezi Erdiansyah \\ karincharviaa@gmail.com,rezie@fikom.untar.ac.id \\ Fakultas Ilmu Komunikasi Universitas Tarumanagara
}

\begin{abstract}
This study aims to determine the effect of electronic word of mouth and brand experience on brand trust of OVO users in Jakarta. Data collection by distributing questionnaires to 100 respondents. The data analysis method in this study uses SEM through the Lisrel 8.70 application. The results showed that there was a significant influence of electronic word of mouth and brand experience on brand trust. Between the two dependent variables, what has a greater influence on brand trust is electronic word of mouth. The conclusion of this research to improve brand trust can be done by improving electronic word of mouth and brand experience.
\end{abstract}

Keywords: brand experience,, brand trust, electronic word of mouth, ovo users in jakarta

\begin{abstract}
Abstrak
Penelitian ini bertujuan untuk mengetahui pengaruh electronic word of mouth dan brand experience terhadap brand trust para pengguna OVO di Jakarta. Pengumpulan data dengan melakukan penyebaran kuesioner kepada 100 responden. Metode analisis data dalam penelitian ini menggunakan SEM melalui aplikasi Lisrel 8.70. Hasil penelitian menunjukkan bahwa terdapat pengaruh yang signifikan electronic word of mouth dan brand experience terhadap brand trust. Diantara kedua variabel dependen maka yang memiliki pengaruh lebih besar terhadap brand trust adalah electronic word of mouth. Kesimpulan dari penelitian ini untuk meningkatkan brand trust dapat dilakukan dengan cara memperbaiki electronic word of mouth dan brand experience.
\end{abstract}

Kata Kunci: Brand Trust, Electronic Word of Mouth, Brand Experience, Pengguna OVO di Jakarta

\section{Pendahuluan}

Pada era globalisasi kini, berkembangnya teknologi yang pesat menciptakan inovasi dalam bidang bisnis. Perusahaan harus mampu membangun rasa kepercayaan merek dalam diri konsumen agar dapat mencapai bisnis yang sukses. Kepercayaan konsumen terhadap suatu merek diartikan sebagai brand trust. Chi, Yeh dan Chiou (dalam Hidayah 2016:125) mengemukakan bahwa brand trust merupakan kepercayaan konsumen terhadap merek bahwa produk yang ditawarkan oleh merek dapat diandalkan seperti kelengkapan fungsi, kualitas yang terjamin dan pelayanan yang dilakukan setelah menjual barang kepada konsumen. Kesesuaian produk pada janji yang ditawarkan, akan menghasilkan penilaian positif konsumen terhadap merek. Penilaian positif konsumen tentu akan menghasilkan kepercayaan. Menurut Kapferer (dalam Febby dan Erdiansyah 2018:69), pentingnya kepercayaan bagi konsumen karena akan membantu konsumen dalam mengurangi risiko dan pengorbanan waktu konsumen terhadap merek. Tarigan dan Siregar (2019:180) juga menyatakan bahwa 
brand trust dapat menjadi senjata utama perusahaan agar dapat bersaing dan tetap menjaga eksistensinya dalam persaingan yang semakin kompetitif. Perusahaan dapat dikatakan berhasil jika mampu membangun pikiran atau ingatan konsumen akan suatu merek dengan cara melakukan strategi pemasaran yang tepat.

Suatu perusahaan untuk dapat membangun kepercayaan dengan konsumen dapat dilakukan dengan berbagai cara, misalnya membangun interaksi kepada khalayak di situs jejaring sosial atau dapat diartikan sebagai electronic word of mouth. Menurut Solia \& Pratomo (dalam Oktaviani et al., 2019), electronic word of mouth merupakan suatu komentar atau rekomendasi dari konsumen lain dari pengalamannya dan komentar ini memiliki pengaruh yang sangat kuat untuk mempengaruhi konsumen lain dalam mengambil keputusan. Membangun interaksi antara perusahaan dengan konsumen dapat dilakukan oleh perusahaan di media sosialnya. Electronic word of mouth selain berguna untuk membangun interaksi dengan konsumen di media sosial, juga berguna untuk membangun strategi pemasaran perusahaan yang efisien demi kelangsungan hidup perusahaan. Jangkauan konsumen dalam electronic word of mouth sangat luas bahkan hingga seluruh dunia. Hal tersebut terbukti dari pernyataan Purnamasari dan Yulianto (2017).

Selain itu, kepercayaan pada merek juga akan tercipta dari Brand Experience seperti yang dinyatakan oleh Ferinnadewi (dalam Trifena dan Hidayat, 2018). Pengalaman konsumen terhadap suatu merek dapat disebut sebagai Brand Experience. Pengalaman dapat berupa pengalaman positif dan pengalaman negatif tergantung pada tingkat kepuasan dan kesesuaian produk atau jasa yang didapat konsumen dari suatu merek.

Brand Experience didefinisikan sebagai suatu respon internal yang meliputi sensasi, kognisi, respon dan perasaan konsumen yang disebabkan oleh merek. Rangsangan yang berasal dari komunikasi pemasaran, desain merek, lingkungan merek dan identitas merek berhubungan dengan respon yang diberikan oleh konsumen dimana merek dipasarkan (Brakus et al., 2009). Brand Experience akan menimbulkan kepuasan konsumen terhadap merek dan mewujudkan hubungan yang melebihi rasa puas dari konsumen terhadap merek. Jika kepuasan konsumen bisa melebihi ekspetasi konsumen, maka dapat membawa konsumen ke dalam hubungan afektif dimana hubungan tersebut lebih penting dari hubungan pribadi antara konsumen dengan brand yaitu brand trust (Pertiwi et al., 2017).

Salah satu bisnis yang sedang berevolusi adalah bisnis digital dalam bidang pembayaran. Penggunaan dompet sebagai alat pembayaran beralih kepada dompet elektronik. Di Indonesia, salah satu dompet elektronik yang sudah banyak digunakan oleh orang adalah OVO. OVO merupakan aplikasi berbasis internet yang digunakan sebagai alat pembayaran dan memberikan keuntungan berupa cashback bagi para penggunanya. Dilansir dari kumparan.co.id, OVO menduduki peringkat kedua penggunaan aplikasi e-Wallet terbesar di Indonesia. Data tersebut diperoleh dari data pengguna aktif bulanan di Google Play dan iOs.

Berdasarkan uraian latar belakang di atas, maka peneliti melakukan penelitian mengenai OVO dan memberikan penelitian ini dengan judul "Pengaruh Electronic Word of Mouth dan Brand Experience terhadap Brand Trust (Studi terhadap pengguna OVO di Jakarta)". 


\section{Electronic Word of Mouth}

Teknologi yang mengalami kemajuan khususnya dalam bidang komunikasi yaitu internet, menghasilkan inovasi baru dari word of mouth menjadi electronic word of mouth dimana penyampaian informasi bersifat luas dan tidak terbatas. Electronic word of mouth diartikan sebagai suatu tempat yang sangat penting dan berguna bagi konsumen untuk dapat membagikan pendapatnya dan lebih efektif daripada word of mouth karena electronic word of mouth menggunakan media internet yang akan menjangkau khalayak lebih luas (Jalilvand dan Samiel, dalam Priansa, 2017). Teori electronic word of mouth menurut Henning-Thurau et al. (dalam Haekal et al., 2016) yaitu suatu pernyataan baik positif atau negatif mengenai suatu produk atau perusahaan yang dibuat oleh pelanggan yang aktual, pelanggan yang potensial atau pelanggan sebelumnya dan informasi disebarkan melalui media internet. Menurut Purnamasari dan Yulianto (2018) menyatakan bahwa kegiatan electronic word of mouth yaitu melakukan pemasaran melalui media elektronik tanpa adanya komunikasi tatap muka (face to face). Penyataan lain yang dikemukakan oleh Gruen (dalam Adeliasari et al., 2014) bahwa eWOM didefinisikan sebagai suatu komunikasi yang berguna untuk saling bertukar informasi tentang suatu produk atau jasa oleh setiap konsumen yang telah konsumsi, kepada konsumen lain yang tidak saling mengenal satu sama lain ataupun pernah bertemu sebelumnya. Goyette et al (dalam Utami dan Saputri 2016) membagi dimensi electronic word of mouth ke dalam 3 dimensi yaitu Intensitas (Intensity), Valence of opinion, dan Konten (Content).

\section{Brand Experience}

Menurut Brakus, Schmitt dan Zarantonello (2009) menyatakan bahwa brand experience merupakan konsep yang dimaksudkan sebagai suatu respon internal yang meliputi sensasi, kognisi, perasaan dan respon konsumen yang disebabkan oleh merek. Rangsangan yang berasal dari desain merek, komunikasi pemasaran, lingkungan merek dan identitas merek berhubungan dengan respon yang diberikan oleh konsumen dimana merek tersebut dipasarkan. Konsumen yang telah mencari, menerima pelayanan, membeli hingga mengkonsumsi produk, akan merasakan pengalaman atas merek produk yang telah di konsumsinya. Namun tidak hanya berkaitan dengan konsumsi suatu produk melainkan melihat suatu iklan atau pemasaran yang dilakukan oleh perusahaan juga akan memberikan pengalaman merek walaupun secara tidak langsung. Menurut Brakus et al (dalam Pertiwi et al., 2017) pengalaman merek terbagi dalam empat dimensi diantaranya sensory, affective, behavioral dan intellectual.

\section{Brand Trust}

Konsumen yang mempercayai suatu merek disebut sebagai brand trust. Menurut Kumar (dalam Syahdiany dan Trinanda, 2019:227) Brand trust didefinisikan "sebagai kerelaan individu mempercayai kemampuan merek untuk memuaskan kebutuhannya." Selain itu, definisi brand trust adalah sebagai suatu keberhasilan brand yang mampu menciptakan suatu pengalaman yang berkesan dalam diri konsumen dan didasarkan pada kejujuran, integritas dan kesantunan brand. (Murthy dalam Kusdianto, 2018:74). Menurut Kautonen dan Karjoluoto (dalam Quraini dan Saputri, 2018:89), pengukuran kepercayaan merek dapat terbagi menjadi dua dimensi yaitu brand reliability dan brand intention. 


\section{Hipotesis}

$H_{1}$ : Electronic Word of Mouth berpengaruh positif dan signifikan terhadap Brand Trust.

$\mathrm{H}_{2}$ : Brand Experience berpengaruh positif dan signifikan terhadap Brand Trust.

\section{Metode Penelitian}

Dalam penelitian ini, peneliti menggunakan metode penelitian kuantitatif. Penelitian kuantitatif adalah metode penelitian yang memiliki landasan filsafat positivisme yang berguna untuk melakukan penelitian mengenai suatu populasi atau sampel tertentu, lalu instrumen penelitian digunakan untuk melakukan pengumpulan data dan menganalisis data yang bersifat kuantitatif bertujuan untuk menguji hipotesis yang telah ditentukan (Sugiyono 2017).

Survey dalam penelitian ini menggunakan 20 indikator pernyataan yang dibuat berdasarkan dimensi dari setiap variabel. Variabel electronic word of mouth memiliki enam indikator dari ketiga dimensi menurut Goyette et al (dalam Utami dan Saputri, 2016:2). Variabel brand experience memiliki 8 indikator dari keempat dimensi menurut Brakus et al. (dalam Pertiwi et al., 2017), dan variabel brand trust memiliki empat indikator dari kedua dimensi menurut Kautonen dan Karjaluoto (dalam Quraini dan Saputri, 2018).

Kuesioner atau angket digunakan oleh peneliti sebagai metode pengumpulan data dalam penelitian ini. Menurut Sugiyono (2017:142), kuesioner adalah metode pengumpulan data yang dilakukan secara tertulis dengan memberikan responden beberapa pertanyaan atau pernyataan dan responden memberikan jawaban. Instrumen penelitian yang digunakan sebagai pengukuran adalah skala Likert. Pengukuran skala Likert berisikan berbagai penyataan yang sistematis dengan tujuan untuk menunjukkan sikap responden terhadap pernyataan (Prasetyo dan Jannah, 2013:110). Menurut Siregar (2013:25), skala Likert merupakan skala yang digunakan untuk melakukan pengukuran tentang sikap, pendapat dan persepsi seseorang terhadap suatu objek atau fenomena tertentu. Penelitian dengan skala Likert memiliki nilai dari lima (5) hingga satu (1).

Dalam melakukan analisis data yang bertujuan untuk mendapatkan hasil uji validitas, uji reliabilitas dan data karakteristik responden, peneliti menggunakan SPSS versi 15.0. Untuk mengetahui apakah terdapat pengaruh dari hasil hipotesis dan menentukan hasil diterima atau tidak, maka dilakukan uji analisis data. Metode SEM (Structur Equation Model) dengan software LISREL 8.70 digunakan untuk melakukan analisis data dalam penelitian. Menurut Ferdinand (dalam Efendy dan Suryadinata, 2015:619) SEM merupakan kumpulan teknik statistikal yang memungkinkan untuk melakukan pengujian pada sebuah rangkaian hubungan yang relatif "rumit" secara simultan atau bersama-sama.

\section{Hasil Temuan dan Diskusi}

Berdasarkan usia responden, mayoritas usia responden dalam penelitian ini yaitu 20-25 tahun sebanyak 70 orang dan memiliki presentase $70 \%$. Yang kedua, responden dengan usia lebih dari 36 tahun sebanyak 21 orang dan memiliki presentase $21 \%$. Usia responden kisaran 26-30 tahun sebanyak 6 orang dengan presentase $6 \%$ dan usia responden yang memiliki jumlah terkecil adalah usia 31-45 tahun sebanyak 3 orang dengan memiliki presentase $3 \%$. Berdasarkan jenis kelamin, hasil responden 
yang berjenis kelamin laki-laki sebanyak 46 orang dan memiliki presentase $46 \%$ dan responden sebanyak 54 orang merupakan jenis kelamin perempuan dengan presentase $54 \%$. Selanjutnya berdasarkan profesi, responden mahasiswa memiliki jumlah sebanyak 48 orang dengan presentase $48 \%$, responden kedua yaitu wirausaha sebanyak 15 orang dengan presentasi $15 \%$, responden ketiga yaitu karyawan sebanyak 25 orang dengan presentase $25 \%$ dan responden yang menjawab lain-lain sebanyak 12 orang dengan presentase $12 \%$. Berdasarkan domisili, responden yang berdomisili di Jakarta utara memiliki jumlah sebanyak 24 orang dengan presentase $24 \%$, domisili Jakarta barat sebanyak 29 orang dengan 29\%. Selanjutnya domisili Jakarta timur sebanyak 8 orang dengan presentase $8 \%$. Domisili Jakarta pusat sebanyak 12 orang dengan presentase $12 \%$ dan yang terakhir domisili Jakarta selatan sebanyak 27 orang dengan presentase $27 \%$.

\section{Model Pengukuran}

Penelitian ini menggunakan uji validitas yang bertujuan untuk mengetahui valid atau tidak nilai yang terdapat dalam kolom corrected item total correlation dan dihitung menggunakan program SPSS. Menurut Nisfianoor (2013:233) untuk mengetahui suatu butir dinyatakan valid atau tidak valid, maka digunakan patokan 0.2. Jika angka korelasi memiliki hasil di bawah 0.2, akan dinyatakan tidak valid dan jika angka korelasi memiliki hasil di atas 0.2 akan dinyatakan valid. Lalu dilakukan uji reliabilitas dalam penelitian ini bertujuan untuk mengetahui pernyataan yang disebarkan melalui kuesioner dapat diandalkan atau dipercaya. Menurut Maholtra (dalam Tingkir 2014:65) variabel dapat dinyatakan reliabel jika nilai Cronbach's Alpha > 0.6 dan data tersebut dinyatakan layak untuk digunakan pada penelitian selanjutnya. Nilai Cronbach's Alpha melalui uji reliabilitas dalam penelitian ini masing-masing memiliki nilai lebih dari 0.6 sehingga variabel layak dikatakan reliabel. Untuk melakukan uji hipotesis penelitian menggunakan metode untuk mengolah data yaitu SEM dengan LISREL 8.70 dengan nilai T Values > T tabel 1.96.

Tabel 1 Hasil Uji Validitas

\begin{tabular}{|c|c|c|c|}
\hline Variabel & Indikator & $\begin{array}{l}\text { Corrected } \\
\text { Item Total } \\
\text { Correlation }\end{array}$ & Keterangan \\
\hline \multirow[t]{5}{*}{$\begin{array}{l}\text { Electronic Word } \\
\text { of Mouth }\end{array}$} & $\begin{array}{ll}\text { Saya mengakses } & \text { informasi } \\
\text { tentang } & \text { OVO di media sosialnya }\end{array}$ & 0.370 & Valid \\
\hline & $\begin{array}{l}\text { Saya sering berinteraksi dengan } \\
\text { pengguna lain di media sosial } \\
\text { OVO }\end{array}$ & 0.373 & Valid \\
\hline & $\begin{array}{l}\text { Saya merekomendasikan kepada } \\
\text { orang lain untuk menggunakan } \\
\text { OVO }\end{array}$ & 0.568 & Valid \\
\hline & $\begin{array}{l}\text { Saya memperoleh informasi } \\
\text { yang positif tentang OVO dari } \\
\text { pengalaman pengguna lain di } \\
\text { situs jejaring sosial }\end{array}$ & 0.591 & Valid \\
\hline & $\begin{array}{l}\text { Saya memperoleh informasi } \\
\text { tentang kualitas OVO di akun } \\
\text { media sosialnya }\end{array}$ & 0.581 & Valid \\
\hline
\end{tabular}




\begin{tabular}{|c|c|c|c|}
\hline & $\begin{array}{l}\text { Saya memperoleh informasi } \\
\text { tentang promo cashback OVO di } \\
\text { akun media sosialnya }\end{array}$ & 0.353 & Valid \\
\hline \multirow[t]{8}{*}{ Brand Experience } & $\begin{array}{l}\text { Saya merasa nyaman } \\
\text { menggunakan OVO sebagai alat } \\
\text { untuk bertransaksi }\end{array}$ & 0.572 & Valid \\
\hline & $\begin{array}{l}\text { Saya sangat tertarik melihat } \\
\text { spanduk promosi OVO }\end{array}$ & 0.495 & Valid \\
\hline & $\begin{array}{l}\text { Saya merasa lebih baik } \\
\begin{array}{l}\text { bertransaksi } \\
\text { menggunakan OVO }\end{array}\end{array}$ & 0.651 & Valid \\
\hline & $\begin{array}{ll}\text { Saya merasakan } & \text { keuntungan } \\
\text { ketika } & \text { bertransaksi } \\
\text { menggunakan OVO } & \\
\end{array}$ & 0.666 & Valid \\
\hline & $\begin{array}{l}\text { Saya menjadi lebih konsumtif } \\
\text { dengan menggunakan OVO }\end{array}$ & 0.510 & Valid \\
\hline & $\begin{array}{l}\text { Saya merasa pembelian menjadi } \\
\text { lebih murah dengan } \\
\text { menggunakan OVO }\end{array}$ & 0.673 & Valid \\
\hline & $\begin{array}{l}\text { OVO memberikan panduan } \\
\text { mengisi saldo yang benar }\end{array}$ & 0.503 & Valid \\
\hline & $\begin{array}{l}\text { OVO memberikan informasi } \\
\text { tentang maksimal cashback yang } \\
\text { akan diterima }\end{array}$ & 0.532 & Valid \\
\hline \multirow[t]{6}{*}{ Brand Trust } & $\begin{array}{l}\text { Saya benar-benar mendapatkan } \\
\text { cashback yang sesuai oleh OVO }\end{array}$ & 0.451 & Valid \\
\hline & $\begin{array}{lcc}\text { Saldo saya di OVO terbukti } \\
\text { aman dan tidak } & \text { pernah } \\
\text { mengalami masalah } & \\
\end{array}$ & 0.381 & Valid \\
\hline & $\begin{array}{l}\text { Saya merasa bertransaksi } \\
\text { menggunakan OVO menjadi } \\
\text { lebih praktis }\end{array}$ & 0.496 & Valid \\
\hline & $\begin{array}{l}\text { Saya dapat menemukan kontak } \\
\text { customer service di aplikasi } \\
\text { OVO }\end{array}$ & 0.595 & Valid \\
\hline & $\begin{array}{l}\text { Customer service OVO sangat } \\
\text { cepat dalam menangani kendala } \\
\text { pengguna }\end{array}$ & 0.624 & Valid \\
\hline & $\begin{array}{l}\text { Customer service OVO dapat } \\
\text { mengatasi masalah yang dialami } \\
\text { oleh pengguna }\end{array}$ & 0.669 & Valid \\
\hline
\end{tabular}

Tabel 2 Hasil Uji Reliabilitas

\begin{tabular}{ccc}
\hline Variabel & Nilai Cronbach's Alpha & Keterangan \\
\hline Electronic Word of Mouth & 0.730 & Reliabel \\
\hline Brand Experience & 0.838 & Reliabel \\
\hline Brand Trust & 0.785 & Reliabel \\
\hline
\end{tabular}


Karin Charvia, Rezi Erdiansyah: Pengaruh Electronic Word of Mouth dan Brand Experience terhadap Brand Trust (Studi terhadap pengguna OVO di Jakarta)

Tabel 3 Hasil Pengujian Hipotesis

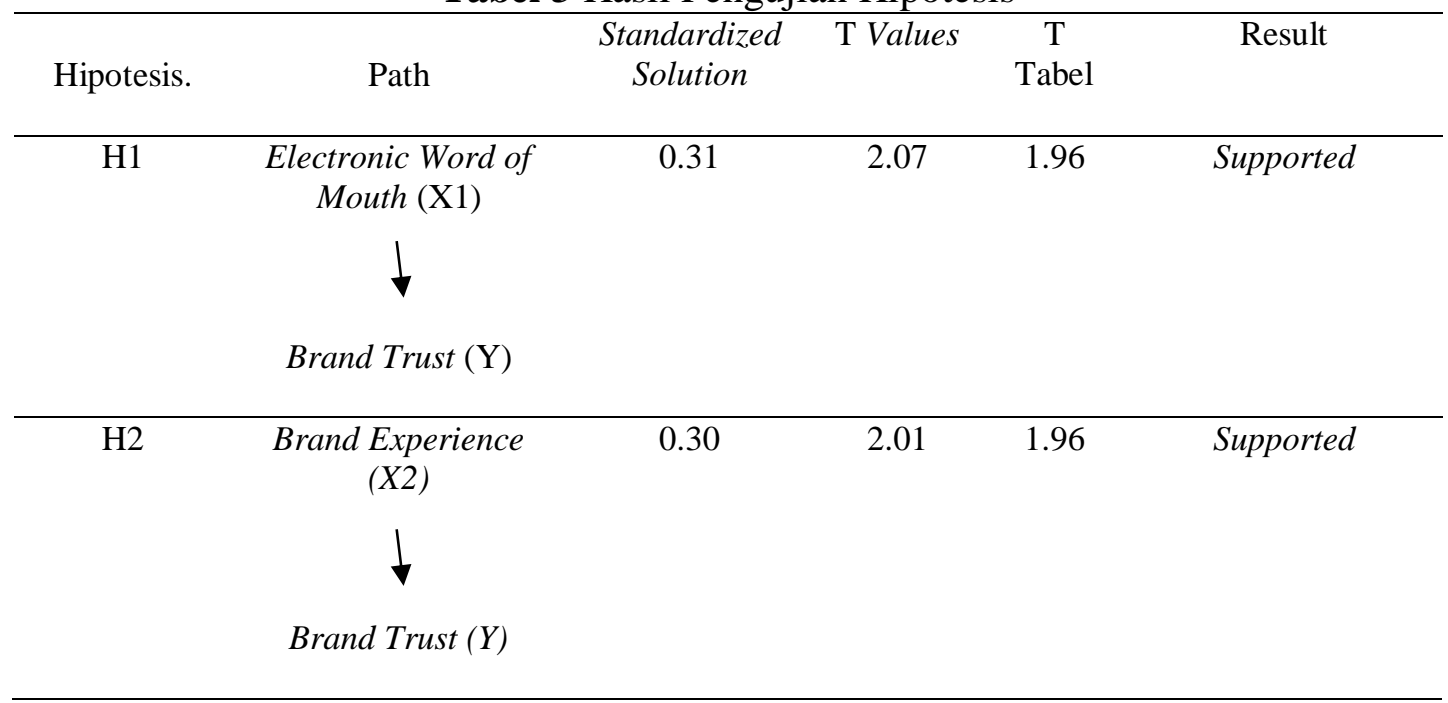

Sumber : Data diolah dengan LISREL SEM 8.70

\section{Diskusi}

Berdasarkan tabel 3 dapat dilihat bahwa semua hipotesis positif dan signifikan. Pada hipotesis 1 memiliki hasil H1 diterima yang dapat diartikan bahwa variabel electronic word of mouth memiliki pengaruh positif dan signifikan terhadap brand trust. Dengan demikian, semakin tinggi electronic word of mouth yang dilakukan oleh pengguna media sosial tentang OVO maka akan meningkatkan kepercayaan merek (brand trust). Seperti pada hasil penelitian yang dilakukan oleh Twinarutami dan Hermiati (2013) yang berjudul "Pengaruh Electronic Word Of Mouth (eWOM) Terhadap Kepercayaan Merek Pada Media Sosial di Kalangan Mahasiswi (Studi Pada Produk Body Lotion Nivea)" menyatakan bahwa electronic word of mouth memiliki pengaruh positif dan signifikan terhadap kepercayaan merek.

Pada hipotesis 2 memiliki hasil $\mathrm{H} 2$ diterima yang dapat diartikan bahwa variabel brand experience memiliki pengaruh positif dan signifikan terhadap brand trust. Dengan demikian, semakin tinggi brand experience konsumen terhadap OVO maka akan meningkatkan kepercayaan merek (brand trust). Seperti pada hasil penelitian yang dilakukan oleh Arthana dan Susilowati (2013) yang berjudul "Pengaruh Brand Exposure dan Brand Experience terhadap Brand Trust dan Brand Recall (Studi pada Produk Smartphone di Wilayah Kota Malang)" menyatakan bahwa brand experience memiliki pengaruh positif dan signifikan terhadap brand trust.

\section{Simpulan}

Berdasarkan hasil yang didapat dari penelitian, maka penulis dapat menarik kesimpulan dari penelitian ini adalah sebagai berikut:

1. Electronic word of mouth memiliki pengaruh positif dan signifikan terhadap Brand Trust

2. Brand Experience memiliki pengaruh positif dan signifikan terhadap Brand TrustPenulis menyampaikan rasa terima kasih yang sedalam-dalamnya kepada Albert, Leonardo, Viola, Kevin dan kepada seluruh pihak yang telah membantu serta memberikan kontribusi dalam penelitian ini sehingga dapat terselesaikan dengan baik. 


\section{Ucapan Terima Kasih}

Penulis menyampaikan rasa terima kasih yang sedalam-dalamnya kepada Albert, Leonardo, Viola, Kevin dan kepada seluruh pihak yang telah membantu serta memberikan kontribusi dalam penelitian ini sehingga dapat terselesaikan dengan baik.

\section{Daftar Pustaka}

Arthana, Rony N. C. (2016). Pengaruh Brand Exposure dan Brand Experience Terhadap Brand Trust dan Brand Recall (Studi pada Produk Smartphone di Wilayah Kota Malang). Jurnal Ekonomi Bisnis Tahun 21 No. 2, 201-213.

Brakus, Schmitt, \& Zarantonello. (2009). Brand Experience:What Is It? How Is It Measured? Does It Affect Loyalty? Journal of Marketing, 52-68.

Hidayah, R. T. (2016). PENGARUH BRAND TRUST TERHADAP NIAT KONSUMEN UNTUK MELAKUKAN PEMBELIAN PRODUK ELEKTRONIK PADA SITUS JUAL BELI LAZADA. Journal University of Jember, 122-132.

Ir. Syofian Siregar, M. (2013). Metode Penelitian Kuantitatif Dilengkapi Perbandingan Perhitungan Manual \& SPSS. KENCANA PRENADAMEDIA GROUP.

Kusdianto. (2018). ANALISIS PENGARUH BRAND EXPERIENCE TERHADAP BRAND TRUST DAN DAMPAKNYA PADA CUSTOMER SATISFACTION PRODUK KAOS POLO PADA PENGUNJUNG AEON MALL BSD CITY. Jurnal Manajemen Bisnis Vol. 7 No. 2, 73-80.

Naulia Oktaviani, W. A. (2019). PENGARUH KEPUASAN KONSUMEN TERHADAP PEMBENTUKAN KOMITMEN PELANGGAN DAN e-WOM PADA PENGGUNA APLIKASI e-MONEY “OVO”. Jurnal Manajemen dan Pemasaran Jasa, 93-112.

Nisfiannoor, M. (2013). PENDEKATAN STATISTIKA MODERN Aplikasi dengan Software SPSS dan EViews. Jakarta: Universitas Trisakti.

Priansa, D. J. (2017). Komunikasi Pemasaran Terpadu pada Era Media Sosial.

Pricilla Efendy, Y. A. (2015). ANALISA PENGARUH BRAND IMAGE DAN BRAND TRUST TERHADAP BRAND LOYALTY DI RESTORAN D'COST SURABAYA. Jurnal Hospitality dan Manajemen Jasa Vol. 3, No. 2 , 613-627..

Saputri, H. Q. (2018). PENGARUH BRAND TRUST DAN COSTUMER SATISFACTION PRODUK GO-MOBILE TERHADAP CONSUMER LOYALTY PADA PT BANK CIMB NIAGA TBK. JURNAL MANAJEMEN DAN BISNIS (ALMANA) VOL. 2 NO.2, 89.

Sugiyono, P. D. (2016). METODE PENELITIAN Kuantitatif, Kualitatif, dan R\&D. Bandung: PT. Alfabet.

Tingkir, C. F. (2014). PENGARUH IDENTITAS MEREK TERHADAP LOYALITAS MEREK MELALUI CITRA MEREK DAN KEPERCAYAAN MEREK TOYOTA. Jurnal Manajemen Pemasaran Vol. 8 No. 2, 62-69. 